\title{
Supernaturalism in Samuel Taylor Coleridge's Major Poems
}

\author{
1) Nurbaiti Ali ${ }^{2)}$ Doni Efriza \\ ${ }^{1,2)}$ Universitas Pembangunan Panca Budi (UNPAB) \\ ${ }^{1)}$ baityoni@gmail.com ${ }^{2}$ defriz19@gmail.com
}

\begin{abstract}
Samuel taylor coleridge's the ancient mariner and kubla khan are the major poems regarded as the greatest compositions in the field of supernaturalism. As a poet of supernaturalism, coleridge strictly eschewed crudeness from his writings. Based on the purpose of this study, that is to seek supernaturalism in samuel taylor coleridge's major poems, the research design of this study is conducted by applying content analysis as proposed by koul (1984). Content analysis is concerned with the phenomenon, elements and comparison. Because of its concern, content analysis is sometimes referred to as 'documentary activity' or 'information analysis'. The data of this study belong to the non -manipulated variables as they are not the result of experiment; these are called the qualitative type. Therefore, the data analyzed with the qualitative descriptive approach. This research will show the nature of the situation as it exists at the time of the study as stated by gay (1987: 189), "descriptive research determines and reports the way the things are". Dream, suggestiveness and vision are the elements of the supernaturalism in these poems which are presented in the research result.
\end{abstract}

Keywords : Coleridge, Poems, Supernaturalism

\section{INTRODUCTION}

\subsection{Background of the Study}

Supernaturalism, in general, is anything that goes beyond nature, reasoning, something unexplained by logical grounds. The supernatural beliefs have already existed in many cultures, tradition throughout human history. Supernaturalism, a belief in an otherworldly realm or reality that, in one or another, is commonly associated with forms of religion.

Samuel Taylor Coleridge possesses the most vigorous mind among the English Romantic poets, whereas in other poets of this period, romanticism tends to take a single dominant hue which colors the objects of experience, in Coleridge it attains a fullness of complexity. In his poetry, there is room for the spirit of bold adventure, the joy of discovery and the romance of action. The essence of Coleridge's romanticism lies in his artistic treatment of Supernaturalism in English Literature.

There are three major works of Samuel Taylor Coleridge, The Ancient Mariner, Kubla Khan, and Christable. All of his three major works are poems of pure Supernaturalism. Kubla Khan, is less directly concerned with the supernatural, still Supernaturalism touches in the 'woman wailing for her demon-lover', in 'the ancestral voices prophesying war' and in the demoniac energy with which the mighty fountain is momently forced from the deep romantic chasm and this is quite unmistakable. Towards the end of the poem, the poet caught in a spell of creative inspiration transcends his mundane existence and is transformed into a purely supernatural being.

The distinctive feature of Supernaturalism is presentation of the essential pscychological truth. The supernatural touched in Kubla Khan and The Ancient Mariner are so well managed that they are in perfect harmony with the mental and emotional moulds of the characters as well as the readers. Supernaturalism for a certain extend is something natural in the sense that numerous incidents, events or even experiences that appear to be illogic as yet easily accepted. A simple instance is dream, which is truly a supernatural phenomenon and for some people dream is simply a part of sleep yet for some others a dream is interpreted into various points. The major poems of Coleridge have a strange dreamlike atmosphere. Dreams with him are of shadows; they are the very substance of his life. He is 
fed on his dreams and vitalizes them in his poems. Kubla khan is essentially a dream poem recounting in a poetic from what he sees in a vision. It is an exquisite dream poem. It is not only composed in a sort of dream but even exhibits a dream-like movement. The Ancient Mariner comes from Cruikhshank's dream and displays a dreamlike movement. It is a number of dream characteristics which have been skillfully exploited to give the poem its inner logic. And when the poem ends, it clings to the memory with the peculiar tenacity of a dream. Coleridge, then as already stated is fed on his dreams and vitalizes them in his poems. This dream-like quality of poetry also contributes to his romanticism.

\subsection{Problem of the Study}

Referring to the background of the study, there are two questions formulated as follows:

1. Are The Ancient Mariner and Kubla Khan poems of supernaturalism?

2. What are the elements of Supernaturalism found in these poems?

\subsection{Objectives of the Study}

This research is aimed at analyzing Supernaturalism in Samuel Taylor Coleridge's major poems:

1. To reveal that The Ancient Mariner and Kubla Khan are poems of Supernaturalism.

2. To reveal that some elements of Supernaturalism such as, Dream, Suggestiveness, and Vision are found in "The Ancient Mariner" and "Kubla Khan".

\subsection{Significance of the Study}

Samuel Taylor Coleridge's The Ancient Mariner and Kubla Khan are regarded as the poems of Supernaturalism. In these poems salient elements of Supernaturalism such as "Dream, Vision and Suggestiveness are found in everyday life.

Every story has something special to study, and Samuel Taylor Coleridge's insightful Supernatural poems, The Ancient Mariner and Kubla Khan poems, are not difference. The broadest application is to know that life is worthy of trust. Other lessons are to be cautious about taking conclusions in our life, so that we do not go in the way to achieve our dream or vision in our life.

Several precious lessons, such as to avoid the high fantasy and not to become opiumer are well presented through these poems. Above all, Supernaturalism exists in every aspect of human life. The priest now is to make a proportional filtration.

\subsection{Scope of the study}

In a scientific study the problem must be limited to make the analysis done accurately. The writer makes a study on Supernaturalism in Samuel Taylor Coleridge's major poems The Ancient Mariner and Kubla Khan, and she limits the study to distinctive parts of Supernaturalism: Dream, Suggestiveness, and Vision.

\section{LITERATURE REVIEW}

\subsection{Theories of Supernaturalism}

Supernaturalism is belief that there are beings, forces, and phenomena such as God, angels or miracles which interact with the physical universe in remarkable and unique ways. Supernaturalism is fundamental premise of theism. Theists by definition hold to a supernaturalistic worldview which stands in contrast to the atheistic premise of naturalism, which denies the existence of any Supernaturalism phenomena.

The Ancient Mariner and Kubla Khan by S.T.Coleridge are regarded as poems of Supernaturalism and by virtue of these poems Coleridge is named as the greatest poet of the Supernaturalism in English 
Literature. These poems represent the full flowering of his genes; they are "such stuff as dreams are made on". And his main contribution to poetry is his subtle appeal to the romantic sense for the supernatural.

Her lips were red, her looks were free,

Her locks were yellow as gold

Her skin was white as leprosy,

The Night-mare Life-in-Death was she,

Who thicks man's blood with cold

(The Ancient Mariner, lines: 190-194)

A Savage place! As holy and enchanted

As e'er beneath a waning moon was haunted

By woman wailing for her demon-lover.

(Kubla Khan, lines: 14-16)

Supernaturalism is suggestive, psychological and refined, not crude and sensational (S.T. Coleridge: 1772-1834).

The concept of Supernaturalism is generally identified with religion, although there is much debate as to whether a conception of the Supernaturalism is necessary for religion. Generally, people contrast the supernatural and some believe that these two concepts are compatible or complementary, while others believe that they are incompatible and in competition. Nevertheless, many claims of supernatural phenomena often conflict directly and fundamentally with current scientific understanding.

According to William James in The Variety of Religious Experience (1902) there have been many attempts to verify claims of supernatural phenomena scientifically. All are generally considered failures, although proponents often claim to show startling and unusual results. The supernatural is also a topic in various genres of fiction, such as fantasy and horror. Some examples of supernatural phenomena are miracles, ghost, psychic abilities which are better classified as paranormal than supernatural.

Supernaturalism is a part of nature that the modern science is incapable of explaining. Science cannot examine things, which are unexamined. Therefore Supernaturalism is a system believed to be more flexible allowing us more diversity in terms of epistemology. Before the flourishing of science, everything has a supernatural cause and consequently in this scientific era, we are still dependent on Supernaturalism (Prof. Barlley Smith: 1927).

\subsubsection{Magic}

Magic is the claimed art of altering things either by supernatural means or through knowledge of occult natural laws unknown to science. It is in contrast to science, in that science does accept anything not subject to either director or indirect observation, and subject to logical analysis, whereas practitioners of magic claim it is an inetplicable force beyond logic.

In A General Theory of Magic (1972), Marcell Mauss classifies magic as a social phenomenon to religion and science, but yet a distinct category. In practice, magic bears a strong resemblance to religion. Both the using are similar types of rites, materials, social roles and relationships to accomplish aims and engender belief. They both operate on similar principles, in particular those of consecration and sacredness of objects and places, interaction with supernatural powers mediated by an expert, employment of symbolism, sacrifice, purification and representation in rites, and the importance of tradition and continuation of knowledge. 
Magic and religion is also share a collective character and totally of belief. The rules and powers of each are determined by the community's ideals and beliefs and so many slowly evolve. Additionally neither supports partial belief. Belief in one aspect of the phenomena necessitates belief in the whole, and each incorporates structural loopholes to accommodate contradictions.

\subsubsection{Miracle}

Miracle is an unexpected event attributed to divine intervention. Sometimes an event is also attributed to a miracle worker saint or religious leader. A miracle is sometimes thought of as a perceptible interruption of the laws of nature. Others suggest that God may work with the laws of nature to perform what people perceive as miracles. Theologians say that, with divine providence, God regularly works through created nature yet is free to work without, above, or against it as well.

In one view, miracle is a phenomenon not fully explainable by known "laws" of nature, or an act by some supernatural entity or unknown, outside force. Some scientist-theologians such as John Polkinghorne (2007) suggest that miracles are not violations of the laws of nature but "exploration of a new regime of physical experience".

A miracle is often considered a fortuitous event: compare with an Act of God. In casual usage, miracle may also refer to any tatistically unlikely but beneficial event, (such as surviving a natural disaster), or simply a wonderful occurrence, regardless of likelihood, such as a birth. Other miracles might be: survival of a terminal illness, escaping a life threatening situation or 'beating the odds'. Some coincidences may be perceived to be miracles.

\subsection{Theoretical Framework}

\subsubsection{Dream}

Dream, physiologically is a reaction or response to neural processes during sleep, it is the work of the subconscious mind overloaded but spiritually dream is a revelation of a divine message or predictions of the future that is usually to be acted upon (Stevens, 1952).

The poems of Coleridge have a strange dreamlike atmosphere about them. Dreams with him are no shadows, they are the very substances of his life. He fed on his dreams and vitalized them in his poems. Kubla khan is essentially a dream poem recounting in a poetic form what he saw in a vision. The Ancient Mariner comes from Cruickshank's dream and displays a dreamlike movement.

C.M. Bowra in the Romantic Imagination illustrates the affinity of The Ancient Mariner with a dream. "On the surface it shows many qualities of a dream, " says Bowra. "It moves in an abrupt stages, each of which has its own single, dominating character. Its visual impressions are remarkably brilliant and absorbing.

The atmosphere of dream is to accustom us to the special world and then proceed to create freely within chosen limits. Dreams can have a curiously vivid quality which is often lacking in waking impressions. In dreams, we have one experience at a time in a very concentrated form and since the critical self is not at work, the effect is more powerful and more haunting than most effects when we are awake.

\subsubsection{Vision}

Vision is new efforts focused on the visual effects of material theories of light, to light accompanied by a constant urge to explain sensation, perception, imagination, memory and cognition by means of invisible mechanism (Dr. Robert. A. Hatch).

Vision is a power of seeing or imagining looking ahead, grasping the truth that underlies facts. In this case, Coleridge presents vision of Kubla Khan as a fragment and vivid images. These points have garnered extensive critical attention through the years, and it has long been acknowledged as a poetic 
representation theories of imagination and creation. Coleridge possesses an unusual gift of evoking the mystery of things. He has an eye for subtleties that could give an uncanny look even to what is just commonplace.

The Ancient Mariner is made a mysterious character just by the mention of his glittering eye, long grey beard and skinny hand. Coleridge uses this faculty most effectively while making the ordinary natural phenomena like the rising of the sun and the moon, blowing of the winds and the twinkling of the stars assume a mysterious character. Mast-high ice sending a dismal sheen and making cracking and growling sound is bound to appear mysterious. And no less mysterious should be the bizarre spectacle of the death-fires dancing in real and rout and water burning green, and blue and white like a witch's oils. The romantic chasm in Kubla Khan is given a touch of mystery by the mention of the 'woman wailing for her demon-lover'.

\subsubsection{Suggestiveness}

Suggestiveness is tending to bring ideas into the mind. Suggestiveness can be defined as facts about how it interacts with shared human faculties of intellect and imagination. Suggestiveness is a very important ingredient in Coleridge's Supernaturalism. Suggestiveness adds a touch of subtlety to the poem and enhances both the supernatural mystery of the poem and its vague and subdued horror.

The Ancient Mariner describes the reality of Life-in-Death teasingly indeterminate and yet suggestive enough to convey her dreadfulness. This helps Coleridge to avoid any crude horrors commonly employed by the writers of Gothic romances. He also makes up for the inadequacy of his pictures through describing their effects on the minds of his characters.

In Kubla khan, this suggestiveness is seen even to a better advantage. In this poem, the description of deep romantic chasm slanting down the green hill across a cedarn cover is perhaps unsurpassed for its sheer suggestiveness. The supernaturalism in Kubla Khan does not strain our sense of probability because the dramatic truth of human experience projected in it is nowhere falsified. Kubla Khan abounds in suggestive phrases and lines capable of evoking mystery. The description of the romantic chasm, the source of the river Alph in the second part of the poem is romantic in spirit.

\section{RESEARCH METHOD}

\subsection{Research Design}

The research design refers to all processes which are needed in planning and doing a research. The research design is different from the research purpose. Based on the purpose of this study, that is to seek the Supernaturalism in Samuel Tailor Coleridge's major poems, the research design of this study is conducted by applying content analysis as proposed by Koul (1984). Content analysis is concerned with the phenomena, elements and comparison the content of documents.

This research will show the nature of the situation as it exists at the time of the study as stated by Gay (1987: 189), "descriptive research determiners and reports the way the things are". This research is also qualitative since all the data collection is in the form of words. There is only one kind of sources of data in this research, that is, the poems of The Ancient Mariner and Kubla Khan by Samuel Taylor Coleridge.

\subsection{Source of Data}

Following Herbert's theory (1990) that a library research is a research to collect ideas, theories, and reported empirical data within the context of scholarship the library, then, the data in this research will be collected from many sources, especially books and websites. Books which are related to the subject matter of this research are those concerning Supernaturalism in Samuel Taylor Coleridge's major poems, The Ancient Mariner and Kubla Khan. The whole text scripts of the poems are used as the 
main sources of data.

\subsection{Data Collection Procedures}

To collect the data, the researcher first chooses the poems that contain some aspects of Supernaturalism in Samuel Taylor Coleridge's major poems.

\subsection{Data Analysis Procedures}

After all the data were collected, the next step is data analysis, where the collected data from the poems were analyzed using the following steps:

1. Coding the data based on the types of the Supernaturalism in found in the poems of The Ancient Mariner and Kubla Khan.

2. Discussing and summarizing the findings. In this step, the writer analyzes a number of arguments indicating the Supernaturalism in The Ancient Mariner and Kubla Khan poems.

\section{RESEARCH RESULT}

\subsection{Analysis}

As stated before, Supernaturalism is the main concept in The Ancient Mariner and Kubla Khan. Without Supernaturalism, there is no reason for the readers to have a feeling of dream, suggestiveness, and vision.

\subsubsection{Poems of Supernaturalism}

The Ancient Mariner is a supreme triumph of poetry. By virtue of this poem alone can Coleridge claim a rank among the masters of romantic poetry. The crime, the punishment, the torture, the relief, and the partial forgiveness are the main events of this poem which may be regarded as Coleridge's masterpiece.

This poem offers an example of what may be called realistic Supernaturalism. The greatness of the poem lies in the skill with which the supernatural has been made to appear natural. There are no doubt, impossible and fantastic elements in the poem, the magnetic power in the Mariner's gaze. The dreadful silence of the far seas, the sudden appearance of a skeleton-ship, the spectre-woman and her deathmate, the coming back to life of the dead crew, the polar spirit, etc.

Kubla khan is also a triumph of Supernaturalism. In it, the images which had been deposited in the unconsciuos mind of Coleridge from his reading about Subterranean rivers, pleasure palaces, and other marvelous things, emerged to his conscious mind and were expressed immediately and spontaneously in words.

The Supernaturalism in Samuel Taylor Coleridge's major poem in The Ancient Mariner and Kubla Khan become an interesting topic to be discussed.

\subsubsection{Elements of Supernaturalism}

The essence of Coleridge's romanticism lies in his artistic treatment of the supernatural. All of his three important poems The Ancient Mariner, Kubla Khan and Christabel are poems of pure Supernaturalism. As a poet of the supernatural, Coleridge strictly eschewed crudeness from his writings. He gives supernatural his supernatural the solid base of the dramatic truth of human emotions so that howsoever improbable the events might appear, the authenticity of human experience is never violated.

He just suggests, giving his readers a free hand to use their imagination and fill in the necessary details. Instead of abruptly stepping into the realm of the supernatural, he first wins the faith of his readers with an accurate rendering of the familiar landscape and then slowly proceeds to exploit this 
faith and introduce the supernatural elements. Here, there are three elements of Supernaturalism, dream, suggestiveness and vision.

\title{
4.1.3 Dream
}

Romantic quality is a Supernaturalism. One of Supernaturalism based upon a dream. Dream, physiologically is a reaction or response to neural process during sleep, it is the work of the subconscious mind overloaded but spiritually dream is a revelation of a divine message or predictions of the future that is usually to be acted upon. (Stevens, 1952).

Kubla Khan is an exquisite dream poem. It is not only composed in a sort of dream but even exhibits a dream poem. In The Ancient Mariner, a number of dream characteristics have been skillfully exploited to give a poem its inner logic. This poem, exactly like a dream, moves in abrupt stages, each of which has its own single, dominating character. The poem shows Coleridge's pictorial power and range. Many of these nature pictures are richly colored. Here is an exquisite picture of mist, snow, and ice bergs. See the quotation below:

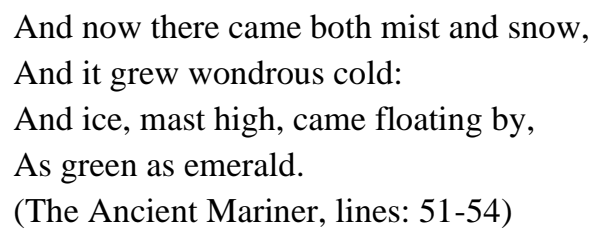

From the quotation above, the ship reaches the region where there is mist and haze. It also grows intensely cold. Mast high ice bergs, shining like the green emerald, came floating near the ship.

In the Samuel Taylor Coleridge major poem Kubla Khan, the great oriental king, once orders that a magnificent pleasure-palace be built for him in Xanadu where the sacred river Alph winding its course through immeasurably deep caves ultimately sink into a dark, subterranean sea. See the quotations below:

\author{
In Xanadu did Kubla Khan \\ A stately pleasure-dome decree \\ Where Alph.the sacred river, ran \\ Through caverns measureless to man \\ Down to a sunless sea \\ So twice five miles of fertile ground \\ With walls and towers were girldled round \\ And there were gardens bright with sinuous rills, \\ Where blossomed many an incease-bearing tree; \\ And here were forests ancient as the hills, \\ (Kubla Khan, lines: 1-10)
}

Kubla Khan, the great oriental king, orders a magnificent pleasure palace to be built in his capital city Xanadu. The palace is to be situated on the bank of the sacred river Alph, which, flowing through immeasurably deep caves, ultimately sank into a dark, subterranean sea. So, a piece of fertile land, ten square miles in area, is enclosed with walls and towers.

\subsubsection{Suggestiveness}

In The Ancient Mariner, Coleridge has rigidly excluded the conventional, crude presentation of the supernatural elements. This depiction is suggestive and tentalisingly indeterminate, exercising an effect of vague mystery. There are no horrifying details in the description of the Night mare Life-in- 
Death:

Her lips were red, her looks were free,

Her locks were yellow as gold;

Her skin was as white as leprosy,

The Night-mare Life-in-Death was she,

Who thicks man's blood with cold.

(The Ancient Mariner, lines: 190-194)

From the quotation above, it is seem that the woman's lips are red; her hair is golden yellow; and she has very bold, audacious looks. Her skin is as white as that of a person struck with leprosy. That horrible woman is Life-in-Death. She is a nightmare personified and is capable of curdling any man's blood.

In Kubla Khan,Coleridge makes us of subtle suggestions in the description of deep romantic chasm slanting down the gren hill across a cedarn cover. See the quotation below:

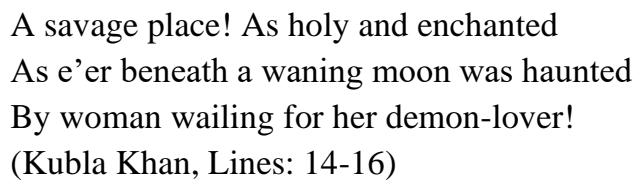

It is a wild, awe inspiring piece of scenery where magic influences seems to be at work. it is the kind of place visited again and again by woman who, after falling in love, discovers that her lover is demon and who, in her distress, is searching for him in the pale light of the waning moon.

The supernatural in Kubla Khan does not strain our sense of probability because the dramatic truth of human experience projected in it is nowhere falsified. Kubla Khan abounds in suggestive phrases and lines capable of evoking mystery. The description of the poem is romantic in spirit.

\title{
4.1.4 Vision
}

The Ancient Mariner Coleridge has given details of the description of vision. See the quotation below:

\author{
The fair breeze blew, the white foam flew, \\ The furrow followed free; \\ We were the first that ever burst \\ Into that silent sea. \\ (The Ancient Mariner, lines: 103-106)
}

A favorable gentle wind blows. The white foam flows off from the surface of the ocean. The ship sails onward calmly and the track made by it is clearly visible. It seems to them that they are the first people who have ever come to that silent sea.

Kubla Khan is a poem about the act of poetic creation, about the "ecstasy in imaginative fulfillment". The whole poem is about the possibilities and potentialities of the creative power:

Could I revive within me

Her symphony and song,

To such a deep delight would win me,

That with music loud and long,

I would build that dome in air.....

(Kubla Khan, lines: 42-46) 
Coleridge here describes the act of poetic creation. The poet is the creator. The poet creates lovely forms and shapes with the power imagination. But in other to do so, the poet needs inspiration. Something must stir, excite, urge the poet to create. Coleridge recalls a dream that he once sees the dream of an Abyssinian maiden playing on a dulcimer and singing sweetly. He says that is he could recapture the music and melody of that girl, it would be a source of great inspiration to him. If he could exactly remember the music of that girl, he would go into an ecstasy of joy. In that mood of ecstasy or rapture, he would write such excellent poetry that the readers would be able to see that sunny pleasure dome and those caves of ice in their imagination.

\section{CONCLUSION}

Samuel Taylor Coleridge's major poems The Ancient Mariner and Kubla Khan fulfill this aim. Supernaturalism is a romantic quality. Coleridge takes the supernatural as his field and undertakes to naturalize it. He has achieved his object by skillfully blending the real and fantastic, by giving us a detailed description of the voyage so as to give the whole a diary.

The essence of Coleridge's romanticism lies in his artistic treatment of the supernatural. The major poems in Kubla Khan and The Ancient Mariner are poems of pure supernaturalism. He first takes his reader around familiar places and wins his faith in the narrative through vividly portrayed minute details. The important features of Coleridge's treatment of the supernaturalism is a very clever and subtle blending of the natural and the supernatural. Indeed the two are so indistinguishably fused with each other that it becomes difficult to locate where the one ends and the other begins.

The elements of the supernaturalism in Coleridge's major poems become an interesting topic to be discussed, especially in the poems like The Ancient Mariner and Kubla Khan. Furthermore, these poems are also the reflection of human reality to touch the tender chords capable of producing still, sad music of humanity. Supernaturalism is something natural and there are numerous incidents, events or even experiences that can be seen as supernatural elements. The distinctive elements of Supernaturalism such as dream, suggestiveness and vision already exposed.

\section{REFERENCES}

Abrams, M.H.(1953). Romantic Theory and The Critical Tradition. Oxford: Oxford University Press. Bronislow Malinowski. 1935. The Language of Magic and Gardening. Dover: New York.

Bowra, C.M.1949. The Romantic Imagination. London: Oxford University Press.

Claude, Strauss. 1978. Myth Meaning. New York: New York Press.

Coleridge and Wordsworth. 1970. The Poetry of Growth. Cambridge: Cambridge University Press.

Freud, Sigmund. (1994). The Interpretation of Dreams. New York.

Frazer, James. 1915. A Study Magic and Religion. London: Macmillan.

Hatch, Robert. (1990). Theories of Vision. Florida: University of Florida Press.

James, William. 1902. The Varieties of Religious Experience. Scotland: Edinburgh University Press.

Koul, Lokesh. 1984. Methodology of Educational Research (the $3^{\text {rd }}$ revised edition). New Delhi: Vihas Publishing House PVT LTD.

Lall, Ramji. 1989. S.T Coleridge “An Evaluation of His Poetry”. New Delhi: New Delhi University Press. Lewis, C.S.1947. Miracles: A Preliminiary Study. New York: Macmillan.

Smith, Barlley. 1927. Astronomical Images. London: Thames Inc.

Stevens, Mac. 1952. Dreams and Meanings. Finland: Finland University.

Taylor, Samuel. 1772. The Concept of Supernaturalism. Cambridge: University of Cambridge Press. 